\title{
Synthesis, Characterization, and Application of Indolo[3,2-b]carbazole Semiconductors
}

Pierre-Luc T. Boudreault ${ }^{\mathrm{a}}$, Salem Wakim ${ }^{\mathrm{a}, \mathrm{b}}$, Nicolas Blouin ${ }^{\mathrm{a}}$, Michel Simard ${ }^{\mathrm{c}}$, Christian Tessier $^{\mathrm{d}}, \mathrm{Ye} \mathrm{Tao}^{\mathrm{b}}$ and Mario Leclerc ${ }^{\mathrm{a} *}$

a) Canada Research Chair on Electroactive and Photoactive Polymers, Département de Chimie, Université Laval, Quebec City, Quebec, Canada, G1K 7P4 email : mario.leclerc@chm.ulaval.ca

b) Institute of Microstructural Sciences, National Research Council of Canada, Ottawa, Ontario, Canada, K1A 0R6

c) Laboratory of X-ray Diffraction, Department of Chemistry, Université de Montréal, Montreal, Quebec, Canada, H3C 3J7

d) Département de Chimie, Université Laval, Quebec City, Quebec, Canada, G1K 7P4

\section{Supporting information}

\section{Synthesis}

Materials. All starting organic compounds were purchased from Aldrich, Alfa Aesar and TCI America and used without further purification. All reactions were carried out under argon at 1 atm unless mention otherwise. Column chromatography was carried out on silica gel (Size 40 - $63 \mu \mathrm{m}$, Pore size $60 \AA$, Silicycle). The synthesis of 2,8- and 3,9dibromo-5,11-dihydroindolo[3,2-b]carbazole ${ }^{1}$ and $\mathrm{Pd}\left(\mathrm{PPh}_{3}\right)_{4},{ }^{2}$ stored under argon at 
$-20^{\circ} \mathrm{C}$ and used within 48 hours, have been already reported in the literature. The syntheses of 5,11-dioctylindolo[3,2-b]carbazole (OIND), 5,11-bis $(p$ octylphenyl)indolo[3,2- $b]$ carbazole $\quad$ (OPIND), 5,11-bis( $p$-hexylphenyl)indolo[3,2$b$ carbazole (HPIND), and 5,11-bis(5-hexylthiophene)indolo[3,2-b]carbazole (OTIND) have already been reported in the literature. ${ }^{1,3}$ All other compounds have been synthesized following procedures described here.

General indolo[3,2-b]carbazole alkylation procedure. ${ }^{1}$ A freshly prepared $50 \%$ aq. $\mathrm{NaOH}$ solution $(11 \mathrm{~mL})$ was added to a well-stirred mixture of dibromo-5,11dihydridoindolo[3,2-b]carbazole, $2(2.250 \mathrm{~g}, 5.430 \mathrm{mmol})$, benzyltriethylammonium chloride (0.250 g, $1.09 \mathrm{mmol})$, 1-bromooctane (4.190 g, $21.70 \mathrm{mmol})$, and DMSO (54 $\mathrm{mL}$ ) in a $250-\mathrm{mL}$ flask under an argon atmosphere. The mixture was stirred at room temperature for $1 \mathrm{~h}$ and then heated at $65^{\circ} \mathrm{C}$ and maintained at this temperature for $4 \mathrm{~h}$. Subsequently the reaction mixture was cooled down to room temperature and poured into $300 \mathrm{~mL}$ methanol with stirring. The precipitated yellow solid was filtered off and washed with water, and 3 times each with $N, N$-dimethylformamide, methanol, and acetone.

\section{2,8-dibromo-5,11-dioctylindolo[3,2-b]carbazole (3): Following the general} indolocarbazole alkylation procedure afforded $3.240 \mathrm{~g}$ of the title product as a yellow solid. M.P.: $196^{\circ}$ C. (Yield: 94\%).

${ }^{1} \mathbf{H}$ NMR $\left(400 \mathrm{MHz}, \mathrm{CD}_{2} \mathrm{Cl}_{2}, \mathrm{ppm}\right): \delta 8.06(\mathrm{~d}, \mathrm{~J}=8.2 \mathrm{~Hz}, 2 \mathrm{H}) ; 8.02(\mathrm{~s}, 2 \mathrm{H}) ; 7.59(\mathrm{~d}, \mathrm{~J}=$ $1.1 \mathrm{~Hz}, 2 \mathrm{H}) ; 7.32(\mathrm{dd}, \mathrm{J}=1.4$ and $8.2 \mathrm{~Hz}, 2 \mathrm{H}) ; 4.36(\mathrm{t}, \mathrm{J}=7.4 \mathrm{~Hz}, 4 \mathrm{H}) ; 1.93(\mathrm{~m}, 4 \mathrm{H})$; $1.32(\mathrm{~m}, 20 \mathrm{H}) ; 0.86(\mathrm{t}, \mathrm{J}=7.0 \mathrm{~Hz}, 6 \mathrm{H})$. 
${ }^{13} \mathrm{C}$ NMR $\left(100 \mathrm{MHz}, \mathrm{CD}_{2} \mathrm{Cl}_{2}, \mathrm{ppm}\right):{ }^{13} \mathrm{C}$ NMR experiment cannot be performed on this compound due to very low solubility in common deuterated solvent.

HRMS calculated for $\mathrm{C}_{34} \mathrm{H}_{42} \mathrm{~N}_{2} \mathrm{Br}_{2}: 636.1715 \quad$ found : $636.1699 \pm 0.0019$

\section{3,9-dibromo-5,11-dioctylindolo[3,2-b]carbazole (4): Following the general} indolocarbazole alkylation procedure afforded $3.270 \mathrm{~g}$ of the title product as a yellow solid. M.P.: $189^{\circ}$ C. (Yield: 95\%).

${ }^{1}$ H NMR (400MHz, $\left.\mathrm{CD}_{2} \mathrm{Cl}_{2}, \mathrm{ppm}\right): \delta 8.32(\mathrm{~d}, \mathrm{~J}=1.6 \mathrm{~Hz}, 2 \mathrm{H}) ; 8.01(\mathrm{~s}, 2 \mathrm{H}) ; 7.56(\mathrm{dd}, \mathrm{J}=$ 1.6 and $8.7 \mathrm{~Hz}, 2 \mathrm{H}) ; 7.33(\mathrm{~d}, \mathrm{~J}=8.7 \mathrm{~Hz}, 2 \mathrm{H}) ; 4.38(\mathrm{t}, \mathrm{J}=7.2 \mathrm{~Hz}, 4 \mathrm{H}) ; 1.92(\mathrm{~m}, 4 \mathrm{H}) ; 1.32$ $(\mathrm{m}, 20 \mathrm{H}) ; 0.85(\mathrm{t}, \mathrm{J}=6.7 \mathrm{~Hz}, 6 \mathrm{H})$.

${ }^{13} \mathrm{C}$ NMR $\left(100 \mathrm{MHz}, \mathrm{CD}_{2} \mathrm{Cl}_{2}, \mathrm{ppm}\right):{ }^{13} \mathrm{C}$ NMR experiment cannot be performed on this compound due to very low solubility in common deuterated solvent.

HRMS calculated for $\mathrm{C}_{34} \mathrm{H}_{42} \mathrm{~N}_{2} \mathrm{Br}_{2}: 636.1715 \quad$ found : $636.1699 \pm 0.0019$

2,8-bis(thien-2'-yl)-5,11-dioctylindolo[3,2-b]carbazole (2TOIND) (6): In a flame-dried flask, compound 3 (0.300 g, $0.472 \mathrm{mmol}), 2$-(tributylstannyl)thiophene (0.528 g, 1.41 mmol) and anhydrous THF $(9 \mathrm{~mL})$ were mixed. The resulting mixture was degassed under vigorous flow of argon for $1 \mathrm{~h}$. Palladium tetrakis(triphenylphosphine) (0.022 g, $0.030 \mathrm{mmol}$ ) was then added and the mixture was refluxed for $16 \mathrm{~h}$. The reaction was cooled to room temperature, poured into water and extracted three times with dichloromethane. The combined organic layers were dried over $\mathrm{MgSO}_{4}$ and the solvent was removed under reduced pressure. The crude brownish product was purified by 
column chromatography (Silica gel, 20\% dichloromethane in hexanes as eluent) to provide $0.139 \mathrm{~g}$ of the title product as a yellow solid. M.P.: $203{ }^{\circ} \mathrm{C}$. (Yield $=46 \%$ ).

${ }^{1}$ H NMR (400MHz, THF-d 8, ppm) : $\delta 8.49(\mathrm{~d}, \mathrm{~J}=1.1 \mathrm{~Hz}, 2 \mathrm{H}) ; 8.26(\mathrm{~s}, 2 \mathrm{H}) ; 7.74(\mathrm{dd}, \mathrm{J}=$ 1.4 et $8.5 \mathrm{~Hz}, 2 \mathrm{H}) ; 7.49(\mathrm{~d}, \mathrm{~J}=8.5 \mathrm{~Hz}, 2 \mathrm{H}) ; 7.40(\mathrm{~d}, \mathrm{~J}=3.0 \mathrm{~Hz}) ; 7.29(\mathrm{~d}, \mathrm{~J}=4.8 \mathrm{~Hz}, 2 \mathrm{H})$; $7.08(\mathrm{dd}, \mathrm{J}=1.1$ and $3.7 \mathrm{~Hz}) ; 4.51(\mathrm{t}, \mathrm{J}=7.1 \mathrm{~Hz}, 4 \mathrm{H}) ; 1.98(\mathrm{~m}, 4 \mathrm{H}) ; 1.36(\mathrm{~m}, 20 \mathrm{H}) ; 0.85$ $(\mathrm{t}, \mathrm{J}=6.8 \mathrm{~Hz}, 6 \mathrm{H})$.

${ }^{13}$ C NMR (100MHz, THF-d $\left.8, p p m\right): \delta 147.10 ; 142.47 ; 137.78 ; 128.77 ; 126.02 ; 125.01 ;$ $124.54 ; 124.20 ; 124.09 ; 122.55 ; 118.50 ; 109.72 ; 100.37 ; 44.03 ; 33.02 ; 30.66 ; 30.43 ;$ $30.01 ; 28.39 ; 23.69 ; 14.59$.

HRMS calculated for $\mathrm{C}_{42} \mathrm{H}_{48} \mathrm{~N}_{2} \mathrm{~S}_{2}: 644.3259 \quad$ found : $644.3270 \pm 0.0019$

3,9-bis(thien-2'-yl)-5,11-dioctylindolo[3,2-b]carbazole (3TOIND) (5): This product was obtained (via compound $4(0.150 \mathrm{~g}, 0.236 \mathrm{mmol})$ ) following the same procedure used for the synthesis of compound 2TOIND to provide $0.152 \mathrm{~g}$ of the title product as a yellow solid. M.P.: $228^{\circ} \mathrm{C}$. $($ Yield $=69 \%)$.

${ }^{1}$ H NMR (400MHz, Acetone-d $\left.6, \mathrm{ppm}\right): \delta 8.32(\mathrm{~s}, 2 \mathrm{H}) ; 8.27(\mathrm{dd}, \mathrm{J}=0.4$ and $8.0 \mathrm{~Hz}, 2 \mathrm{H})$; $7.85(\mathrm{~d}, \mathrm{~J}=1.1 \mathrm{~Hz}, 2 \mathrm{H}) ; 7.59(\mathrm{dd}, \mathrm{J}=1.2$ and $3.6 \mathrm{~Hz}, 2 \mathrm{H}) ; 7.52(\mathrm{dd}, \mathrm{J}=1.5$ and $8.1 \mathrm{~Hz}$, 2H); $7.47(\mathrm{dd}, \mathrm{J}=1.2$ and $5.1 \mathrm{~Hz}, 2 \mathrm{H}) ; 7.17(\mathrm{dd}, \mathrm{J}=3.6$ and $5.2 \mathrm{~Hz}, 2 \mathrm{H}) ; 4.60(\mathrm{t}, \mathrm{J}=7.4$ $\mathrm{Hz}, 4 \mathrm{H}) ; 2.79(\mathrm{~m}, 4 \mathrm{H}) ; 1.36(\mathrm{~m}, 20 \mathrm{H}) ; 0.83(\mathrm{t}, \mathrm{J}=6.9 \mathrm{~Hz}, 6 \mathrm{H})$.

${ }^{13}$ C NMR $(100 \mathrm{MHz}$, THF-d 6 , ppm) $: \delta 146.93 ; 143.30 ; 138.03 ; 133.17 ; 128.87 ; 125.27$; $123.93 ; 123.83 ; 123.70 ; 121.45 ; 117.45 ; 106.40 ; 99.87 ; 43.82 ; 33.03 ; 30.62 ; 30.43 ;$ $29.91 ; 28.37 ; 23.69 ; 14.59$.

HRMS calculated for $\mathrm{C}_{42} \mathrm{H}_{48} \mathrm{~N}_{2} \mathrm{~S}_{2}: 644.3259 \quad$ found : $644.3270 \pm 0.0019$ 
2,8-diphenyl-5,11-dioctylindolo[3,2-b]carbazole (2POIND) (8): In a $100 \mathrm{~mL}$ flask, compound 3 (1.000 g, $1.570 \mathrm{mmol})$, phenylboronic acid (0.575 g, $4.72 \mathrm{mmol}), \mathrm{K}_{3} \mathrm{PO}_{4}$ (1.330 g, $6.280 \mathrm{mmol})$, palladium (II) diacetate $(0.007 \mathrm{~g}, 0.013 \mathrm{mmol})$ and 2dicyclohexylphosphino-2',6'-dimethoxydiphenyl (SPhos) (0.011 g, $0.063 \mathrm{mmol}$ ) were mixed. Degassed THF (40 mL) was then added and the mixture was refluxed for $16 \mathrm{~h}$. The mixture was cooled to room temperature and extracted three times with dichloromethane. The combined organic layers were washed with brine and water, dried over $\mathrm{MgSO}_{4}$ and filtered on silica. The solvent was removed under reduce pressure. The crude product was recrystallized in dichloromethane/hexanes mixture to provide $0.803 \mathrm{~g}$ of the title product as a yellow solid. M.P. $196^{\circ} \mathrm{C}$ (Yield: $77 \%$ ).

${ }^{1} \mathbf{H}$ NMR $\left(400 \mathrm{MHz}, \mathrm{CD}_{2} \mathrm{Cl}_{2}, \mathrm{ppm}\right): \delta 8.46(\mathrm{~d}, \mathrm{~J}=1.3 \mathrm{~Hz}, 2 \mathrm{H}) ; 8.13(\mathrm{~s}, 2 \mathrm{H}) ; 7.78(\mathrm{~m}$, $6 \mathrm{H}) ; 7.50(\mathrm{~m}, 6 \mathrm{H}) ; 7.35(\mathrm{t}, \mathrm{J}=7.4 \mathrm{~Hz}, 2 \mathrm{H}) ; 4.45(\mathrm{t}, \mathrm{J}=7.2 \mathrm{~Hz}, 4 \mathrm{H}) ; 1.99(\mathrm{~m}, 4 \mathrm{H}) ; 1.37$ (m, 20H); $0.85(\mathrm{t}, \mathrm{J}=6.8 \mathrm{~Hz}, 6 \mathrm{H})$.

${ }^{13}$ C NMR (100MHz, $\left.\mathrm{CD}_{2} \mathrm{Cl}_{2}, \mathrm{ppm}\right): \delta 142.67 ; 141.78 ; 137.00 ; 131.72 ; 129.34 ; 127.56 ;$ $126.82 ; 125.61 ; 123.79 ; 123.49 ; 119.07 ; 119.06 ; 109.28 ; 99.61 ; 43.96 ; 32.42 ; 30.01 ;$ $29.82 ; 29.39 ; 27.93 ; 23.21 ; 14.43$.

HRMS calculated for $\mathrm{C}_{46} \mathrm{H}_{52} \mathrm{~N}_{2}: 632.4130 \quad$ found : $632.4119 \pm 0.0019$

\section{3,9-diphenyl-5,11-dioctylindolo[3,2-b]carbazole (3POIND) (7): This product was} obtained (via compound $4(0.410 \mathrm{~g}, 0.645 \mathrm{mmol}))$ following the same procedure used for the synthesis of compound 2POIND to provide $0.288 \mathrm{~g}$ of the title product as yellow needles. M.P.: $240^{\circ} \mathrm{C}$. $($ Yield $=68 \%)$. 
${ }^{1} \mathbf{H}$ NMR $\left(400 \mathrm{MHz}, \mathrm{CD}_{2} \mathrm{Cl}_{2}, \mathrm{ppm}\right): \delta 8.26(\mathrm{~d}, \mathrm{~J}=8.0 \mathrm{~Hz}, 2 \mathrm{H}) ; 8.08(\mathrm{~s}, 2 \mathrm{H}) ; 7.78(\mathrm{~d}, \mathrm{~J}=$ 8.0, 4H); 7.64 (s, 2H); $7.50(\mathrm{~m}, 6 \mathrm{H}) ; 7.38(\mathrm{~m}, 2 \mathrm{H}) ; 4.48(\mathrm{t}, \mathrm{J}=7.4 \mathrm{~Hz}, 4 \mathrm{H}) ; 2.00(\mathrm{~m}, 4 \mathrm{H})$; $1.37(\mathrm{~m}, 20 \mathrm{H}) ; 0.85(\mathrm{t}, \mathrm{J}=7.1 \mathrm{~Hz}, 6 \mathrm{H})$.

${ }^{13}$ C NMR (100MHz, $\left.\mathrm{CD}_{2} \mathrm{Cl}_{2}, \mathrm{ppm}\right): \delta 142.81 ; 142.79 ; 139.55 ; 137.22 ; 129.33 ; 128.03 ;$ $127.58 ; 123.06 ; 122.61 ; 120.59 ; 118.11 ; 107.48 ; 99.41 ; 43.87 ; 32.41 ; 30.01 ; 29.81 ;$ $29.37 ; 27.92 ; 23.19 ; 14.40$.

HRMS calculated for $\mathrm{C}_{46} \mathrm{H}_{52} \mathrm{~N}_{2}: 632.4130 \quad$ found : $632.4138 \pm 0.0019$

\section{Instrumentation}

${ }^{1} \mathrm{H}$ and ${ }^{13} \mathrm{C}$ NMR spectra were recorded on a Varian AS400 apparatus in appropriated deuterated solvent solution at $298 \mathrm{~K}$. Chemical shifts were reported as $\delta$ values (ppm) relative to internal tetramethylsilane. Thermogravimetric measurements (TGA) were carried out with a TC-15 Mettler-Toledo apparatus. The heating rate was $10^{\circ} \mathrm{C} / \mathrm{min}$ under a nitrogen atmosphere. Differential scanning calorimetry (DSC) was performed on Perkin-Elmer DSC7 module in conjunction with the Perkin-Elmer thermal analysis controller $\mathrm{TAC} / \mathrm{DX}$ at a heating rate of $10^{\circ} \mathrm{C} / \mathrm{min}$, under a nitrogen flow and calibrated with ultrapure indium. UV-visible absorption spectra were recorded on a HewlettPackard diode-array spectrophotometer (model 8452A) using 1-cm path length quartz cells.

Cyclic voltammetry was carried out in a two-compartment cell with a Solartron potentiostat (model 1287) with a platinum electrode at a scan rate of $50 \mathrm{mV} . \mathrm{s}^{-1}$ against SCE reference electrode in a solution containing tetrabutylammonium perchlorate (TBAP) $\left(10^{-1} \mathrm{M}\right)$ and the oligomer $\left(10^{-4} \mathrm{M}\right)$ in $\mathrm{CH}_{2} \mathrm{Cl}_{2}$. Measurements on the single- 
crystals were made at $200 \mathrm{~K}$ on a Bruker APEX II area detector diffractometer equipped with graphite monochromated $\mathrm{MoK} \alpha$ radiation. The structure was solved and refined using SHELXS-97 and SHELXL-97 (Sheldrick, 1997). The program used for retrieving cell parameters and data collection was APEX $2,{ }^{4}$ while data were integrated using SAINT. ${ }^{5}$ The structures were solved and refined using the SHELXTL package. ${ }^{6}$ All non$\mathrm{H}$ atoms were refined anisotropically. Packing views were drawn using Mercury. ${ }^{7}$ The single crystal structure of 5,11-dioctyl-6,12-dimethylindolo[3,2-b]carbazole has already been published in the literature. ${ }^{8}$ Unfortunatly, we were only able to obtain very small crystals for 2POIND. Those crystals were weakly diffracting at high angles. For that reason, we cut the data to a resolution of 0.93 A since no reflection was observed at higher angles. Even with this cutoff the R(int) value is still high, but the results (errors on bond distances and angles) are relatively good. Moreover, crystals from 3POIND present severe disorder on one of the side chains for each molecule. We tried our best to modelize them, but the thermal parameters for certain atoms (especially those at the end of side chains) are higher than the average. The $U_{\text {eq }}$ values do not exceed 0.15 except in one case $\left(\mathrm{C} 323 ; \mathrm{U}_{\mathrm{eq}}=0.213\right)$.

For the solid-state UV-visible absorption measurements, $300 \AA$ of organic films were thermally evaporated on quartz plates, in an Edwards vacuum chamber $\left(2 \times 10^{-7}\right.$ torr $)$ at a deposition rate of $0.1 \AA^{-1}$, and spectra were carried out on a Varian Cary 50 Bio UVvisible spectrophotometer. Optical bandgaps were calculated from the edge of the solid state UV-visible absorption spectra. 
Out-of-plane X-ray diffraction (XRD) measurements were recorded at room temperature with a Siemens (D5000) diffractometer using $\mathrm{Cu} \mathrm{K} \alpha$ radiation $(\lambda=1.5406)$ at $40 \mathrm{kV}$ and $30 \mathrm{~mA}$. The XRD patterns were obtained using Bragg-Brentano geometry $(\theta-2 \theta)$ from thin films thermally evaporated in an Edwards vacuum chamber $\left(2 \times 10^{-7}\right.$ torr $)$ on (bare, HMDS- and OTS-treated) $\mathrm{SiO}_{2} / \mathrm{Si}$ substrates at deposition rate of $0.1 \AA^{-1}$ for 300 Å. Scanning electron microscopy (SEM) experiments were performed on the same vacuum-deposited thin films using an Hitachi (S-4700) scanning electron microscope at 1-3 keV.

Highly doped n-type Si wafers (resistivity 5-10 $\Omega \mathrm{cm}$ ) with a $6077 \AA$ thick layer of thermally grown $\mathrm{SiO}_{2}$ (unit area capacitance, $C=5.68 \mathrm{nF} \mathrm{cm}^{2}$ ) were used both as the substrate and as the gate electrode. First, all the substrates were cleaned by subsequent soaking in acetone $(5 \mathrm{~min})$, isopropanol in an ultrasonic bath at $80^{\circ} \mathrm{C}(5 \mathrm{~min})$, and deionized (DI) water (10 min). In the case of plain $\mathrm{SiO}_{2}$, the substrates were taken from the DI water, dried with nitrogen (contact angle $\mathrm{H}_{2} \mathrm{O}=30 \pm 3^{\circ}$ ). In the case of HMDS- and OTS-treated $\mathrm{SiO}_{2}$, the substrates were taken from DI water and activated by successive soakings in an $\mathrm{NH}_{4} \mathrm{OH} / \mathrm{H}_{2} \mathrm{O}_{2} / \mathrm{H}_{2} \mathrm{O}(2: 2: 100)$ solution in an ultrasonic bath at $80^{\circ} \mathrm{C}(5$ $\min )$; DI water $(1 \mathrm{~min}) ; \mathrm{HCl} / \mathrm{H}_{2} \mathrm{O}_{2} / \mathrm{H}_{2} \mathrm{O}(2: 2: 100)$ solution in an ultrasonic bath at $80^{\circ} \mathrm{C}$ (5 min); DI water (5 min) and dried with nitrogen. The substrates were then placed into a UV/ozone photoreactor for one hour to remove any residual organic materials and to create a high density of silanol groups at the surface (contact angle $\mathrm{H}_{2} \mathrm{O}$ about $3^{\circ}$ ). The obtained $\mathrm{SiO}_{2} / \mathrm{Si}$ substrates were modified with a self-assembled monolayer (SAM) of HMDS or OTS. The HMDS SAM was deposited from the vapour phase at reduced pressure $(550 \mathrm{mT})$ using a vapour prime system at $135^{\circ} \mathrm{C}$ for 12 min (contact angle $\mathrm{H}_{2} \mathrm{O}$ 
$=78 \pm 3^{\circ}$ ). The OTS SAM was obtained by immersing the substrates in $5 \mathrm{mM}$ octyltrichlorosilane solution in dry hexanes at room temperature for $24 \mathrm{~h}$. After the OTS SAM formation, the substrates were rinsed with hexanes, ultrasonicated in chloroform, acetone, isopropanol and DI water for 5 minutes each, and then heated at $100^{\circ} \mathrm{C}$ for $5 \mathrm{~min}$ (contact angle $\mathrm{H}_{2} \mathrm{O}=104 \pm 3^{\circ}$ ). The $\mathrm{SiO}_{2} / \mathrm{Si}$ substrates were placed in an Edwards multisource evaporator for organic and metal deposition with a base pressure of $2 \times 10^{-7}$ Torr. $300 \AA$ organic films were vacuum-deposited onto the $\mathrm{SiO}_{2} / \mathrm{Si}$ substrates (at both room temperature and elevated temperature, as indicated in the text) from an effusion cell at a deposition rate of $0.1-0.15 \AA / \mathrm{s}$, as monitored by a quartz crystal thickness monitor. The source and drain electrodes were defined by thermally evaporating gold (700 $\AA$ at a deposition rate of $0.35 \AA / \mathrm{s}$ ) through a shadow mask (channel width $=2600 \mu \mathrm{m}$, channel length $=45 \mu \mathrm{m}$ ) on top of the organic thin film forming a top-contact geometry. The OFETs were characterized inside a dark box at room temperature and under ambient atmosphere with an Agilent (4155c) semiconductor parameter analyser.

\section{References}

(1) Wu, Y.; Li, Y.; Gardner, S.; Ong, B. S. J. Am. Chem. Soc. 2005, 127, 614-618.

(2) Coulson, D. R. Inorg. Synth. 1971, 13, 121.

(3) Belletête, M.; Blouin, N.; Boudreault, P. L. T.; Leclerc, M.; Durocher, G. J. Phys. Chem. A 2006, 110, 13696-13704.

(4) Bruker $A P E X 2$, Version 2.0.2. Bruker AXS Inc., Madison, Wisconsin, USA, 2005 .

(5) Bruker SAINT, Version 7.07a. Bruker AXS Inc., Madison, Wisconsin, USA, 2003.

(6) Bruker SHELXTL, Version 6.12. Bruker AXS, Madison, Wisconsin, USA, 2001.

(7) Macrae, C. F.; Edgington, P. R.; McCabe, P.; Pidcock, E.; Shields, G. P.; Taylor, R.; Towler, M.; van de Streek, J. J. Appl. Cryst. 2006, 39, 453-457. 
(8) Wakim, S.; Bouchard, J.; Simard, M.; Drolet, N.; Tao, Y.; Leclerc, M. Chem. Mater. 2004, 16, 4386-4388. 